\title{
The Impact of Fiscal Policy on Economic Growth in Palestine
}

\author{
Suleiman M. Abbadi ${ }^{1}$, Mohammad Olabi ${ }^{2}$, Haytham Owida ${ }^{2}$ \& Abdelfattah Abu-Shokor ${ }^{2}$ \\ ${ }^{1}$ Arab American University of Palestine, Jenin, Palestine \\ ${ }^{2}$ Department of Economics, An-Najah National University, Nablus, Palestine \\ Correspondence: Prof. Suleiman Abbadi, Arab American University, Jenin, Palestine. Tel: 970-599-260-092. \\ E-mail: suleiman.abbadi@aauj.edu
}

Received: June 9, 2021

Accepted: July 11, 2021

Online Published: July 18, 2021

doi:10.5539/ijef.v13n8p51

URL: https://doi.org/10.5539/ijef.v13n8p51

\begin{abstract}
This study aims at finding the impact of fiscal policy with its various instruments such as, current expenditures, capital expenditures, Tax revenues, non-Tax revenues, foreign assistance and value added tax revenues on economic growth in Palestine represented by the rate of growth of real GDP during the period 1996-2018.
\end{abstract}

A Multiple Regression Analysis was used to build the model and test the hypothesis.

The estimated results showed four of the six independent variables have a significant effect on economic growth, with current and development expenditure having a positive effect while tax and non-tax revenue having a negative effect. On the other hand, foreign aid and clearing tax by Israeli authorizations have no significant effect on economic growth, (though, the last one is significant at 10\%).

The study has also found that government expenditures need to be redistributed between current and development expenditures so as to increase the share of development expenditures in order to maintain a high growth rate.

The paper recommends that the tax rate should be reduced on productive projects which are designed to decrease the unemployment rate and increase the rate of growth.

The study has also pointed out to the significance of re-negotiating the Paris accord with the Israeli authorities so as to improve the terms of this accord, especially in the case of collecting the VAT revenues.

Keywords: fiscal policy, economic growth, current expenditures, development expenditures, paris accord, VAT, TAX and non-tax revenues

\section{Introduction}

Fiscal Policy has been known as one of the most effective economic policies to stimulate the economy and to achieve several objectives such as a high rate of economic growth, to decrease the unemployment rate, decrease the rate of inflation, to improve economic efficiency and reallocate resources and improve income distribution.

Economic stability is also closely linked to the role played by fiscal policy (Saad \& Tarawneh, 2016).

The study of the relationship between fiscal policy and economic growth has received great attention by economists and researchers. It was addressed by many economic schools such as the Keynsians and neo-Keynsians who preferred fiscal policy over monetary policy to affect economic growth and economic stability and is better to achieve other economic objective (AL-Ayati, 2017; Maafellah, 2015).

The Palestinian Economy has been facing several obstacles since the establishment of the Palestinian National Authority (PNA) in 1994 after the Oslo Agreement in 1993. The agreement has restricted the Palestinian control over the borders and $70 \%$ of the land as well as water and other resources over huge areas classified as " $\mathrm{C}$ " areas.

The Paris Accord (An agreement which was signed in Paris in 1994) between the Palestinian Authorities and Israel gave Israel the right to collect the VAT on the Palestinian imports and deduct from it the tax on Palestinian exports. Despite the obstacles faced by the Palestinian economy during the past twenty years, the economy showed a growth of about $10 \%$ in some years while showing a negative growth rate in other years. It grew at an average annual rate of $4.5 \%$ between (1996-2018). 
PNA has faced several difficulties in making fiscal policy during the past 20 years due to the increased commitments to spending and the limited tax base and public revenues. It is still depending on foreign assistance which has been averaged of about $\$ 1 \mathrm{bn}$ per year. Due to the increase in government employees to over 170,000, government revenues are still unable to cover its current public expenditures which prevented fiscal policy from achieving one of its most important objectives: Economic Growth (Alabed, 2017).

This study tries to identify the Fiscal Policy in Palestine and its prominent tools, and it attempts to investigate the extent of policy's success in achieving economic growth and identifying the obstacles that stand on the way of achieving its economic objectives.

A model will be built based on the main variables that affect economic growth - mainly revenues and expenditures. They are divided into six variables: two expenditures current and development and four revenues Tax and non-Tax revenues, foreign aid and clearing revenues from VAT on imported goods from Israel and through their ports. Least square method was used in estimation.

The importance of this study stems from the importance of fiscal policy in the economy and the need of the Palestinian economy to achieve high rates of growth in order to decrease the high unemployment rate.

The study will try to find some recommendations to the policy makers to help them in planning and executing an effective fiscal policy to achieve its economic objectives.

The main objectives of the study is to give the reader some identifications about the tools of fiscal policy and the channels they affect economic growth through. It also attempts to specify which tools are the most effective ones in increasing economic growth in Palestine.

The research article is planned as follows:

Section 2 is a summary of the Palestinian economy mainly economic growth and fiscal policy. Section 3 is a review of the relevant literature and previous studies. Section 4 is a methodology and data structure as well as the theoretical model. Section 5 is the regression analysis and the estimated results. Section 6 will summarize the findings and provides the conclusion.

\section{Fiscal Policy and Economic Growth in Palestine}

\subsection{Economic Growth}

Due to political instability, the Palestinian economy fluctuated during the last twenty years with growth rates over 10\% in some years and negative growth rate of about $10 \%$ in some years. Those high negative growth rates were recorded during 2000-2003 due to Israeli invasion of the West Bank, that caused destruction to the infrastructure and demolishing several houses and government buildings as well some factories and farms. But in general the economy grew from $\$ 5.5$ bn in 1996 to $\$ 13.8$ bn in 2018 at fixed 2015 prices. It grew at an average annual growth rate of $4.3 \%$. During the same period, with population growing at a high rate of $2.7 \%$ per year precipitate income grew at an annual rate of $1.35 \%$ from $\$ 2249$ in 1996 to $\$ 3021.4$ in 2018 . While analyzing the GDP, the researchers of this paper have found a big gap between consumption and production. Total consumption represents about $120 \%$ of GDP, while investment spending is high representing about $18 \%$ of GDP. However, most of this investment went to the construction sector. The Palestinian economy also suffers from a structural weakness in the productive sectors in which their share decreased from $42 \%$ in 1987 to $18 \%$ in 2018. This was due to confiscation of arable land, destroying farms and trees, demolishing farm houses and diverting water to the Israeli settlements preventing large agricultural areas from water resources. Simultaneously, the industrial sector has been suffering from lack of raw materials, difficulties in importing machines and equipment due to the Israeli control over the boarders and the opening of wide doors for imports from both Israel and China. This has caused severe damages and sometimes has led to the closure of several factories especially in the textile and footwear sector. The service sector grew at high rates during the last twenty years due to the increase in employment in the public sector after the establishment of the PNA (PCBS - 2019). The Palestinian labor force grew at an annual rate of $2.7 \%$ during the last twenty years and reached over 1 million in 2018. The economy is suffering also from a high rate of unemployment. It declined from $18.2 \%$ in 1995 to $11.8 \%$ in 1999 due to high rates of economic growth and the increase in government employment. But increased thereafter to $26.8 \%$ in 2004, and further to $30.8 \%$ in 2018 (PCBS - 2019).

\subsection{Public Finance}

The government budget has been suffering from a structural deficit due to the increase in public spending at higher rates than government revenues. Total expenditures grew from about $\$ 1 \mathrm{bn}$ in 1996 to about $\$ 4 \mathrm{bn}$ in 2018, they grew at an average annual rate of $6.5 \%$ during this period mainly because of the increase in public sector 
employment, while total revenues grew from $\$ 645.5$ Millions in 1996 to about $\$ 3462.9$ Millions in 2018. The difference has been covered by foreign aid from Arab countries, USA and European countries.

As with regards to expenditures, it is divided into two kinds: current expenditures representing more than $90 \%$ of total expenditures while the rest is development expenditures.

While revenues, on the other hand, is divided into three kinds: Tax revenues (mainly income tax), non-tax revenues from charges on government services and clearing revenues that comes from Israel. According to the Paris Agreement, Israel is responsible to collect the VAT on the Palestinian imports from outside and from Israel, and subtract VAT to Israel from Palestinian exports to Israel, and charge 3\% services on the net amount and deliver the remainder to the PNA every month.

The components of the revenues in 2018 are as follows: Tax revenues were $24.2 \%$, non-tax revenues were $12.4 \%$ and the rest $65.1 \%$ from clearing revenues (VAT). This is why Palestinians have been suffering when the Israeli government hold this amount for several months in their banks as a way of punishment or to put some political pressure on the Palestinian government.

\section{Theoretical Framework and Previous Studies}

\subsection{Theoretical Framework}

The market economic system has gone through several crises, the most important of which was during 1929-1933 (the great depression), which resulted in a decline in economic growth (global recession), rise in unemployment to about $25 \%$ and bankruptcy of many companies and banks.

This resulted in many criticisms to the economic classical theory that was known at the time in which the economy could not correct itself without government intervention. A new economic school led by the British Economist John M. Keynes emerged and put the first pillar of the Keynesian school of economic thought which allowed the fiscal policy to become one of the most important economic policies. Since then there was a significant rise in the volume of literature to examine the effect of the fiscal policy on the economy which cannot be reviewed in one article.

\subsubsection{Definition and Objectives of Fiscal Policy}

There are several definitions of fiscal policy but most economists agree on the following: "Fiscal Policy is the use of fiscal policy instruments to achieve desired objectives to the economy"

The most important objectives that can be achieved by fiscal policy are:

Economic Growth: To achieve high rates of economic growth or to move the economy from recession to expansion.

Decreasing unemployment rate through increased both aggregate demand and aggregate supply, by increasing government expenditures or decreasing revenues or both.

Lowering inflation rate through decreasing aggregate demand and increasing aggregate supply by reducing government expenditures and increasing revenues or both.

Improving income distribution and achieving social justice through income taxes and expenditures on social programs and subsides.

This article will deal with the first objective leaving the others to be addressed by other researchers in the future.

\subsubsection{Fiscal Policy Instruments}

The government can achieve the above objectives through fiscal policy by using two groups of instruments: Spending and Revenues

Government expenditures are classified by economists into three kinds:

Current Expenditures: which represents the government spending on the management of the public facilities such as education, defense, health ... etc. It includes all expenses to help all departments and ministries to perform their functions including paying wages and salaries of public employees in addition to the expenses of necessary purchases from local and foreign markets. This kind of expenditure is regular and periodic and is covered by using current revenues (general fees and taxes).

Development Expenditures: this kind of expenditures aims at increasing the state's capacity to provide services to its citizens and targeted production projects. Such expenses are related to improve the infrastructure of the country on roads, schools, hospitals, government buildings, bridges, dams ... etc. Those are one-time expenditures on a regular basis. They change according to economic, social, and political circumstances. 
Transfer Expenditures: This kind of expenditures aims at diverting part of the state resources from its bath in order to achieve economic social or financial objectives such as the social security payments, supporting prices of basic food stuff or reducing production cost of some necessary goods and payments to service its public debt. In this study transfers will be added to the current expenditures

Government Revenues: in order to make the previous spending, the government needs to collect money from its people. Economists classify these into three types: Taxes revenues, non-taxes revenues and foreign assistance or foreign aid.

Tax revenues classifications can differ from one country to another depending on the kind of taxes they collect. Usually, there are two kinds of taxes: direct taxes and indirect taxes. Direct taxes are the taxes imposed on income and called income tax or on profits (profit tax which is a kind of income tax on corporates or companies) and taxes on properties.

As compared with direct taxes, indirect taxes are the taxes paid first by the producer or the importer and then transferred partially or completely to the consumer such as import tax, production tax, consumption tax, VAT ... etc. In Palestine they call it "clearing tax" which is collected by the Israeli authorities when it's paid by the Palestinians on their imports and transferred to the Palestinian government after discounting $3 \%$ as services and other unpaid debt due to Israel.

Non-Tax revenues which represent all revenues collected by the government as fees on several services the government performs to its people such as trade permission, annual fees on transportation vehicles, mail and stamps ...etc.

Foreign aid are transfers from rich countries to the poor countries usually used for economic development or to support the government to finance its deficit.

\subsubsection{Fiscal Policy and Economic Growth}

Economic growth can be achieved through both government expenditures and government revenues. Current expenditure first causes aggregate demand to increase and thus prices to increase. That will induce producers to produce more output and thus aggregate supply will increase, while development expenditures -when it increases- causes capital formation to increase, elevates the capacity (or capital) of the economy and thus aggregate supply will increase. Both will cause the economy to grow and will improve production, employment and income, while revenues are used in the opposite way. Decreasing revenues causes aggregate demand to increase and then the economy will grow.

\subsection{Previous Studies}

Abu Shukor studied the impact of government expenditures on economic development in the Palestinian Territories during (1994-2000). He used descriptive analysis to show how government expenditures are classified and structured as well as the types of government expenditures that affect economic growth rate. He found that fiscal policy has a weak effect on economic development in the Palestinian Territories. His study concluded to direct government expenditures to education and health sectors because they play an active role in raising the rate of economic growth (Abu-Shukor, 2003).

In a similar study Khafaja studied the impact of government spending on economic growth in the Palestinian economy during (1994-2011). He used a model in which the real output was the independent variable. The development expenditures, wages and salaries, non-wages expenditures and net lending represented the independent variables. He used statistical Eviews program in his analysis. He found that development expenditures and non-wage expenditures have a statistically significant effect on economic growth while wages and salaries expenditures and net lending are not statistically significant (Khafaja, 2011).

A third study by Abu Eida on the impact of government spending on economic growth in Palestinian Territories during (1995-2013) found that there is a positive relationship between total expenditure and current expenditures on economic growth. The study recommended to increase the size of development expenditures in order to increase economic growth, and to make financial reforms in terms of rationalizing, employing and directing government expenditures (Abu Eida, 2014).

A study of the impact of fiscal policy on economic growth in Algeria (1970-2013) found that increasing public spending did not have a significant impact on improving economic growth rates because of poor productive performance which in turn led to poor government multiplier (Tahtan \& Ben Yahya, 2016)

Another study on Algeria using data from the same period shows that public spending has a weak effect in achieving economic balance. It has also found that spending programs were not directed at channels to increase 
and balance productivity in Algeria. They stated that this was due to the government's inefficiency in financial control over investment projects (Jahida \& Bin Azza, 2018).

Saad and Tarawneh (2016) studied the impact of discretionary fiscal policy on Jordan's economic growth during the period (1967-2011). They used the HP filter and OLS and then they used the error vector correction model (VERM). They found a balanced relationship between discretionary fiscal policy and the rates of economic growth in the long run. They recommended that fiscal policy should reflect the business cycle.

A different study tried to find the effectiveness of fiscal and monetary policy in driving economic growth is Saudi Arabia during the period (1986-2012). They focused on two main pillars: fiscal policy through the impact of public spending and monetary policy through the impact of money and interest rate, and the role of both policies in driving economic growth. The study found a high level of relationship between the variables of the independent policies of the two policies and the dependent economic growth variable. But they indicate that the effectiveness of fiscal policy through government spending was greater than the effectiveness of monetary policy in terms of its roll influencing the economic growth (Saedi \& Otaibi, 2015).

A related practical study on Egyptian economy tried to find the impact of fiscal and monetary policies on economic growth between (1991-2013), they used two fiscal policy variables: Public spending and public revenues, besides some monetary indicators such as money supply and credit granted to private sector to find their impact on economic growth of GDP.

They used time series analysis such as static time series test and variance auto regression (VAR) and joint integration testing. They found a negative relationship between public expenditure and GDP in the long run, as well as the absence of moral impact of public revenues on GDP over the long term. The study also found a positive impact of money supply on economic growth. They recommend integrated action between the central bank and the government agencies responsible for fiscal policy (Mohamed, Essa, \& Abdelhadi, 2016).

Macek and Janku (2015) studied the effect of fiscal policy of the economic growth in OECD countries based on institutional conditions of each country during 2000-2012. They used OLS statistical method in their analysis, and they found that government spending has a greater positive impact on countries with poor institutional conditions. This is mainly because these countries spend more on infrastructure that causes higher growth rates while taxes have a negative impact in countries with poor institutional conditions as opposed with better institutional conditions in which taxes have a positive impact.

Morina (2017) analyzed the relationship between the fiscal policy and economic growth in developing countries in the Southeast European countries during 1994-2015. She used OLS method and Housman test and found a positive impact of tax revenues and a negative impact of government spending on economic growth in those countries.

A study on Sub-Saharan Africa During 1990-2012 used OLS method in testing the impact of fiscal policy on economic growth found that some taxes such as payroll, property and inheritance tax were found to have a positive impact on economic growth while production expenditure (expenditures on infrastructure development) hindered growth rates. The study recommended to increase the government expenditures on development projects and to fight corruption and improve the legal system (Ugwuanyi \& Ugwunta, 2017).

Finally a study on fiscal policy and economic growth in developing Asian countries used several predictive models to predict the impact of each variables of revenues and expenditures on economic growth. They found that property tax had a greater positive impact of economic growth than income tax on individuals and companies. Spending on education have also significant impact on economic growth. They recommend governments to increase spending on education, health, and public investment to promote economic growth (Abdon \& Park, 2014).

From the above studies we can notice the differences in findings of the effect of fiscal policy instruments on economic growth. Some studies have found it has a positive effect and others have revealed a negative effect with a few have showed it has no effect. They also show there are differences among countries public spending and tax revenues, having positive impact in one country and negative impact in another, and one or both have an impact and effective one. In relation to monetary and fiscal policies, fiscal policy had a greater effect on economic growth in some countries whereas it has shown the opposite in others. Fiscal policy achieved its desired economic growth objectives when government spending was channeled to productive and investment sector with sustainable productivity. In some studies they also found that a government must control the cost of investment projects, reduce waste of spending, fighting corruption and improve its legal system to improve the effectiveness of fiscal policy on economic growth. 


\section{Methodology and the Econometric Model}

\subsection{The Model and the Data}

This research paper will be based on building an econometric model to show the effect of fiscal policy on econometric growth in Palestine. The rate of growth of GDP used as the dependent variable while all kinds of revenues and expenditures were the independent variables. We used OLS using multiple regression analysis to estimate the effectiveness of the results. Several tests were performed to reach the best model using the logarithm of the first order difference analysis. It should be noted that this model is similar to ones used in the previous studies such as (Tahtan \& Bin, 2016), (Maatallah, 2015), (saad \& tarawneh), (Mohamed et al., 2016) and (Khafaja, 2011).

The rate of growth of GDP was used as the independent variable (RGDPP) while for the dependent variables the following variables were used: current expenditures - CE, Development Expenditures DE, Tax Revenues - TR, Non Tax Revenues - NTR, External Revenues - ES and Clearing Revenues $-\mathrm{CR}$.

\subsection{Data Description}

The data used for the variables of the model were a quarterly data published by the ministry of finance as well as the Palestine Monetary Authority and the Palestinian Central Bureau of Statistics (PCBS). The data cover the period of first quarter of 2008 to the first quarter of 2019. Though the study cover the period 1996-2018 there was no published data on quarterly basis during 1996-2007.

Due to the importance of addressing some of the statistical problems in the model we took the natural Log and the first difference of the variables, thus becoming free of statistical problems. The standard model becomes as follows:

$$
\begin{gathered}
\Delta \log (G D P P)=\beta_{0}+\beta_{1} \Delta \log (C E)+\beta_{2} \Delta \log (D E)+\beta_{3} \Delta \log (T R)+\beta_{4} \Delta \log (N T R)+\beta_{5} \Delta \log (E S)+ \\
\beta_{6} \Delta \log (C R)+\varepsilon
\end{gathered}
$$

In order to test the series related to this paper we sued a multiple Linear Regression Analysis using OLS method while the data was based on the logarithm first order difference analysis.

Where the $\beta_{0}$ represents the value of economic growth when the values of all independent variables is zero, and $\beta_{1}-\beta_{6}$ is the effect of each independent variable on economic growth.

\subsection{Hypothesis Testing}

Based on the review of previous studies we have built the following hypothesis for testing through this model:

1) First Hypothesis: There is no significant statistical relationship between the change in current expenditures and economic growth RGDPP.

2) Second Hypothesis: There is no significant statistical relationship between the change in development expenditures DE and economic growth RGDPP.

3) Third Hypothesis: There is no significant statistical relationship between the change in tax revenues TR and economic growth RGDPP.

4) Fourth Hypothesis: There is no significant statistical relationship between the change in non-tax revenues NTR and economic growth RGDPP.

5) Fifth Hypothesis: There is no significant statistical relationship between the change in external revenues ES and economic growth RGDPP.

6) Sixth Hypothesis: There is no significant statistical relationship between the change in clearing revenues CR and economic growth RGDPP.

\section{Model Estimation and Hypothesis Testing Results}

The following table shows the results of the coefficient of all variables. The results indicate that all variables with the exception of clearance revenues (CR) are significant at 5\% level (ES only significant at 10\% level). As shown by the standard error of the regression and the T statistics. 
Table 1. LSM test results

\begin{tabular}{|c|c|c|c|c|}
\hline \multicolumn{4}{|c|}{ Included observations: } & 44 after adjustments \\
\hline Variable & Coefficient & Std. Error & t-Statistic & p-value \\
\hline C & 0.002 & 0.008 & 0.215 & 0.831 \\
\hline DLOG & 0.155 & 0.067 & 2.300 & 0.027 \\
\hline DLOG(DE) & 0.035 & 0.016 & 2.276 & 0.029 \\
\hline DLOG(TR) & -0.083 & 0.029 & -2.824 & 0.008 \\
\hline DLOG(NTR) & -0.143 & 0.058 & -2.448 & 0.019 \\
\hline DLOG(ES) & -0.027 & 0.014 & -1.957 & 0.058 \\
\hline DLOG(CR) & -0.019 & 0.025 & -0.767 & 0.448 \\
\hline R-squared & 0.351 & Mean dependent var & -0.001 \\
\hline Adjusted R-squared & 0.326 & S.D. dependent var & 0.057 \\
\hline S.E. of regression & 0.050 & Akaike info criterion & -2.997 \\
\hline Sum squared resid & 0.094 & \multicolumn{2}{|c|}{ Schwarz criterion } & -2.713 \\
\hline Log likelihood & 72.940 & Hannan-Quinn criter. & -2.892 \\
\hline F-statistic & 2.983 & Durbin-Watson stat & 2.010 \\
\cline { 3 - 4 } Prob(F-statistic) & 0.011 & \multicolumn{4}{l}{} \\
\cline { 2 - 4 }
\end{tabular}

As for the transactions of independent variables, the results for the Analysis showed that

$$
\begin{gathered}
(R G D P P)=0.002+0.155 \text { DLOG }(C E)+0.035 \text { DLOG }(D E)-0.083 \text { DLOG }(T R)-0.143 \text { DLOG }(\text { NTR }) \\
-0.027 \text { DLOG }(E S)-0.019 \text { DLOG }(C R)+\varepsilon
\end{gathered}
$$

With regards to testing the hypothesis the statistical results have showed the rejection of all hypotheses except the sixth one (no significant effect of clearance tax on economic growth) which was accepted. Expenditures have a positive effect while revenues have a negative effect which complies with the economic theory and with several studies such as: (Tahtan \& Bin, 2016), (Abu, 2014), (Morina, 2017), (ESSA, 2006), (Saad \& Tarawneh, 2016). Regarding the accuracy of the estimate of the rate of economic growth using different independent variables, the results showed the $\mathrm{R}^{2}$ value was " 351 ". This indicates the variables in the model explain that $35.1 \%$ of the change in the growth rate was through the expenditures and revenue variable used in the model. So we can say that fiscal policy has little effect on economic growth because government expenditures are not directed towards education and health. That means it is not directed towards human capital development which plays a vital role in raising the rate of economic growth. Nonetheless, the variance analysis for the model as a whole the resulting value of 0.011 which is less than 5\% shows that the model is statistically influential on the dependent variable with a margin error of $5 \%$.

In order to confirm the validity of the model several tests were used to prove that the model is the best linear unbiased estimator (BLUE) such as: variance inflation fader (NIF) to test co-integration test (Johansen's analysis of co-integration for multi collinearity) grating using Eigen value. The results of their test indicate a rejection of the hypothesis that there is no common integration.

A third test aimed at testing the non-stationary of the variables used unit-root test. The results rejected the null-hypothesis of any variables having a unit root at all levels $1 \%, 5 \%$ and $10 \%$.

Finally a test for serial correlation and Heteroscedasticity tests were conducted. The results show that there is no auto correlation among the errors. Using Breusch-Godfrey Serial correlation LM test shows no serial correlation in the model.

\section{Conclusion and Recommendations}

The results of the study find that the structure of fiscal policy is distorted as current expenditures represent more than $70 \%$ of total expenditure at the expense of development expenditure. More than $50 \%$ of the current expenditure were wages and salaries. In addition a large portion of the foreign aid received by the government was directed to support the budget to pay wages and salaries rather than going to development projects. Revenues from clearing with Israel has been more than $65 \%$ of the total revenues during the last twenty years and has been under control by Israel. It has been subject to withhold by the Israeli authorities for several months on any disagreement with the Palestinian Authority.

The results of the study indicate a significant positive correlation between current and development expenditures with the rate of economic growth. This is consistent with the Keynesian Economic Theory. The study also find a significant negative relationship between domestic revenues (tax and non-tax revenues) with the rate of economic growth. Increased taxes reduce personal income and thus consumption and lower aggregate demand and economic growth. This also agrees with the economic theory. The results indicate no statistical significant relationship at 5\% 
between foreign aid and economic growth, but it becomes significant at $10 \%$. This confirms that foreign aid is linked to the political objects of the donor countries and is affected by the political aspects and relationships. It also indicates the failure to direct this assistance to development projects that may contribute to increase economic growth. Finally, the study finds no statistically significant relationship between clearing revenues and the rate of economic growth, this is due to the Israeli control over these revenues especially on the dates of delivery to the PNA.

Based on the above findings the study recommends the government to review its expenditure and devote more of it to development rather than current expenditures to increase their share in the budget. In addition, it is highly crucial to reduce taxes on productive projects with the aim of raising the rate of economic growth. It should renegotiate the Paris Accord with the Israeli government especially in regards to collecting the VAT on Palestinian imports.

The Palestinian government should find new sources to finance its budget and decrease its dependence on foreign aid. The study concentrated on one objective of fiscal policy and needs more research on the other objectives.

\section{References}

Abdon, A., Estrade, G., \& Lee, M. (2014). Fiscal Policy and Growth in developing Asia (1990-2011) (1st ed.). Filipino: Asian development Bank. https://doi.org/10.1787/222775817802

Abdulqader, R., \& Raaol, M. (2017). The role of fiscal policy in achieving economic stability in Algeria during the period 2000-2006. Algerian Scientific Journal Platform, 7(12), 162-186. https://doi.org/10.1787/047117560050

Abu- Shukor, A. (2013). The impact of Government Expenditures on Economic Development in the Palestinian Territories. Palestine: Palestinian Center for Research and Studies.

Abu-Eida, O. (2015). The Impact of Governmental Expenditures on Economic Growth in the Palestinian Territories: An Empirical Econometric Study during the Period (1995-2013). Journal of Al-Quds Open University, 1(3), 149-177.

Al-Abed, J. (2016). Toward a better future: The Palestinian Economy. Palestine: Palestine Economic Policy Research Institute - MASS.

Al-Ayati, J. (2017). The effect of fiscal policy tools on economic growth (an econometric study of the relationship between fiscal policy tools and economic growth in the case of Algeria. Journal of Economics and Management, 1(4), 1-12. http://dx.dio.org/ 10.37166/2058-000-004-012.

Al-Ayati, J., \& Bin Azzah, M. (2018). Government spending programs and their role in achieving economic goals- Economic analysis based on the magic square theory of Kaldor and data processing through Var model for the case of Algeria. International Journal of Economic Studies, 1(1), 84-106.

Al-Essa, S. (2006). The impact of government spending on economic growth in Saudi Arabia, Kuwait, and the United Arab Emirates (Published M.A dissertation). Saudi Arabia: King Saud University.

Al-Saeeda, H., \& Al-Eteabi, F. (2015). The effect of fiscal policy and monetary policy in raising the rates of economic growth in the Kingdom of Saudi Arabia for the period (1986-2012). The Economic and Human Development Magazine, 6(1), 28-57.

Khafajah, A. (2013). The Impact of Governmental Expenditure on Economic Growth- An Econometric study on the Palestinian economy (1996-2011) (Published M.A dissertation). Gaza: Islamic University.

Maatallah, A. (2015). The Impact of Fiscal Policy on Economic Growth in the Case of Algeria (1970-2012) (Published M.A dissertation). Algeria: University of Abi Bakr Bilkaid.

Macek, R., \& Janku, J. (2015). The impact of fiscal policy on Economic growth depending on institutional conditions. Acta academica karvinieusia. Acta Academica Growth, 15(2), 95-107. https://doi.org/10.25142/aak.2015.021

Morina, K. (2017). Fiscal policy and economic growth: The case of Southeast European countries. Koegju AAB, 2(2), 67-74.

Palestinian Central Bureau of Statistics (PCBS). (1996-2019). Palestinian Economic Performance Reports for the period 1996-2019, Palestine.

Saeed, A., \& Al-Tarawneh, S. (2016). Discretionary fiscal policy and its impact on economic growth during the period (1967-2011). Jordan Journal of Economic Sciences, 3(2), 137-156. https://doi.org/10.12816/0030066 
Sara, M., Essa, S., \& Abdulhadi, R. (2016). The impact of Fiscal and Monetary Policy on Economic Growth: An Empirical Study on the Egyptian Economy. International Journal of Economic Studies, 8(4), 31-54.

Tahtan, M., \& Bin Yahya, N. (2016). The impact of Fiscal Policy on Economic Growth in Algeria (An-Econometric Study During the period 1970-2013. Journal of Economics and Applied Statistics, 12(2), 152-162.

Ugwanyi, V., \& Ugwunta, O. (2017). Fiscal policy \& economic growth: An examination of selected countries in Sub-Saharan Africa. International Journal of Academic Research in Accounting and Finance, 7(1), 117-130. https://doi.org/10.6007/IJARAFMS/v7-i1/2587

\section{Copyrights}

Copyright for this article is retained by the author(s), with first publication rights granted to the journal.

This is an open-access article distributed under the terms and conditions of the Creative Commons Attribution license (http://creativecommons.org/licenses/by/4.0/). 